\title{
ICT Application in the Insurance Industry: Its Impact in Customer Relationship Management
}

\author{
Prof. Asoc. Evelina Bazini \\ University “Ismail Qemali” Vlore, Albania, Faculty of Economy; evelina.bazini@univlora.edu.al
}

Ph.D Filloreta Madani

University “Ismail Qemali” Vlore, Albania, Faculty of Economy; filloreta.madani@univlora.edu.al

\section{Doi:10.5901/ajis.2015.v4n3s1p307}

\begin{abstract}
The insurance companies are getting aware that due to the business environment which is becoming more and more competitive nowadays, their priority should be the control over the final market. That means holding good relationship with customers. Companies can get feedback of what customers are looking for by understanding them better, their choices, preferences and what they expect and what they want from company's product or services offered. The advance in ICT offer new ways of managing relationship. This paper try to give a better understanding of the effects of ICT in customer relationship management in the insurance industry in Albania. In order to be more competitive in the market, the question is: "How are the insurance companies adopting the latest Information Technology advances and is this a good tool for creating adding value to the product they offer?"
\end{abstract}

Keywords: ICT, insurance company, customer relationship management.

\section{Introduction}

Ryals and Payne (2001) argue that the success of the CRM strategy is found in the customer value. The marketing manager should avoid the marketing myopia. That means, the primary driver for the customer value should be long term relationships with customer and not products on themselves. Of course, for a successful implementation of the CRM strategy, cross-functional working and structural organizational changes will be needed too. In order to have a successful CRM strategy, the company should know how to effectively use its information sources. These information will help them to a better position in the competitive environment, and a strong engagement in relationship with their actual customers, and new possibilities to capture new ones. The possibility of using new ways in relationship management is offered by advances in ICT.

\section{The Customer Satisfaction in the Insurance Industry}

To be competitive to the market, a company may consider a lot of ways, which can lead it to better serving the customer. Among these ways of competition, the most effective one is not considered any more the aggressiveness towards the competitions in terms of market share, but the aggressiveness towards customers serving that lead to their loyalty. Keeping a customer loyal is a real challenge for the company and it poses the need for the creation of the competitive advantage. Insurance companies, as part of the services industry, trying to define the boundary of their competitive area, must take into consideration the large number of competitors, the old ones, other insurance companies, and the new ones brokerage companies and banks. In these circumstances, creation of the competitive advantage is considered a very difficult job. The advances in ICT emerges as a way to facilitate the creation of the competitive advantage using information which can lead the company to the creation of knowledge. Getting to know better its customer's needs and desires, enable the company to serve the customers in the better way ever compared to its competitors. It's obvious and the insurance companies are more aware that there are not the rates which are important for the creation of the competitive advantage any more.

Another difficulty faced by insurance companies during the process of product delivery may by misunderstanding by the customer, which if not managed on time can cause serious problems of customer satisfaction and as a result to 
the customer loyalty. So the main concern should be customer satisfaction, that means the emphasis is placed in the meeting client's requirements. This makes necessary the need to collect, process and use as much as possible information on the clients and their buying behavior, factors that affect their buying decisions. In this sense, new technologies are considered a very useful tool to push and support the insurance companies to look for new sources of competitive advantage. If the company does not have an integrated CRM, this for sure will be a very difficult and expensive for it, and sometimes impossible.

\section{ICT Application in Marketing}

Marketing, as one of the organization functions, has taken advantage from the transformations that ICT use within organization has brought in all its levels. ICT use in caring out marketing activities is considered an important source for creating competitive advantage for the company, focusing in the improvement of the innovation processes and their outcomes. There are a lot of authors that agree on this (Bond and Houston, 2003; Prasad et al., 2001; Roberts, 2000; Tatikonda and Stock, 2003; Tzokas and Saren, 1997). Others, like (Argyres, 1999: Tzokas and Saren, 1997) consider ICT as one of the most appropriate tool for creating knowledge about different agents that are part of the environment in which is operating the organization. From this point of view, the importance of ICT use is appraised in the process of acquisition and generation of the market information. Benefits for the company in this case are measured in terms of quickness, easiness and lower costs as a result of the possibility to have access to relevant and up-to-date information, even though the research results have shown that not always the availability of information leads to knowledge creation. Other authors, (Sorensen and Lundh-Snis, 2001), go a little bit further when they agree that ICT use within the organization is the promotor for the process of transmission and diffusion of knowledge throughout the organization. These knowledge is used later in the decision making process by different levels of management. Performance of marketing functions, provides an important part of the decisions that the organization make. The use of ICT in communication affect directly the level of cooperation, as it is mentioned by Leenders and Wierenga (2002), and taking in consideration that in a close relationship, members of a group share the same principles, culture and values, to achieve the common strategic goal, they agree to use significant resources and make significant efforts. Both McDonough et al. (2001) and Gro"nroos (2000), mentioned that ICT use within organization, results in reduced management costs, which means a great possibility for agents to create social links which by themselves lead to a deeper relationship. Other authors, (Argyres, 1999; Gurviez, 1997; O'Malley and Tynan, 1997), agree that the atmosphere of trust and commitment between agents is a results of the ICT support, and this enables the behavioral cooperation and participation even though sometimes they have to face the cost of losing some of their independence. Based on other research results, ICT use within organization increase its ability to create and maintain long term relationship between different agents and different functional areas. This is proven to be true for both inside and outside of the organization. To be more specific, Leenders and Wierenga (2002); McDonough. et al. (2001) and Rothwell (1994), found out that ICT use resulted in a strengthen collaborative links between different functional areas inside the organization like marketing, research and development and design, while outside the organization, the role of ICT use is seen in the increase of the communication and the level of cooperation with the agents that are part of the relationship, making possible their integration in the organization. As Kahn $(1996,200)$, pointed out, having establishing relationship with external agents, ICT use by organization enables the reinforcement of its ability to coordinate these activities, offering the members of that relationship the possibility to fully participate. Having said that, ICT is considered now as a key marketing factor, and its important is estimated in the new product development process, due to the benefits of its use which result in cost and time saving, facilitation of the information and knowledge transfer, and improvement of the decision making process (Sorensen and Lundh-Snis;, 2001).

\section{The Albanian Insurance Market}

Insurance companies are important player in the economic growth since through risk management isntruments they use, is provided a promotion of the efficent investments. The Albanian Insurance Market is a new one and it is defined as a dynamic one and with continous emerging develoment. There are three important periods of the development of the Insurance Market in Albania since its creation in 1900, when the well-known Londoner insurance company Lloyd's had its branches in three important cities of that time, Durresi, Vlora and Shengjin:

The first period from 1900 to 1944 - All insurances activities were carried out by foreign companies (Londoner, Italian \& French). The insurance Italian companies, that operated in that period were Assicurazione General, Reunione Adriatica, Fonderia Di Firencia Tirana, Instituto Italiana di Previsone, and Roberto Alegro Vlore etc., and the insurance 
services covered by them were the insurance from natural disasters, industrial and life insurance.

The second period from 1944 to 1991 - this was the period of the centralised economy in Albania and there was not a real insurance market since every gathered premium was used according to a plan by the state and the insurance company (Saving and Insurance Institute, a public organization) didn't have its own investment portfolio. Objectives, risks, premiums, regulation and other conditions related with insurances were approved by the Finance Ministry over the proposals of Savings \& Insurance Institute.

The third period from 1991 till now - the democratic changes in Albania had their impact in the economy and in the insurance industry too. The approvememtn of the Law Nr. 7506, in 31 July 1991, brought some changes in the insurance industry. The Saving and Insurance Institute was split up in two different institutions: Savings Bank ans Insurance Institution (INSIG). INSIG was the first Albanian insurnac ecompany that operated as a comercial enterprise and market rules. Another factor that had important impact in the insurance industry in Albania is the Law Nr. 8081, dated on 07.03.1996, "For the insurances and /or reinsurances activities".

\section{Research Methodology}

Data sources used in this paper were primary and secondary. Secondary data were collected through literature review and research results of other studies in this field. Primary data were collected through primary research using a decisionmaker survey about ICT implementation within insurance companies in Albania. This research was financed by the Ministry of Education and Science of Albania through the project for "Fundamental research and excellence". The study consisted on face-to-face interview with decision-makers and employees in insurance companies in Albania. The decision-maker in the enterprises targeted by the survey were both the person responsible for ICT within the company and the marketing manager. The sample used for the data collection was a random one.

\section{Research Results}

The total number of the questionnaires distributed were 120 and the total number of questionnaires returned completed were 87.

When asked for the period of organizing the training program for the computer and other ICT use in the company, 73 of respondents said that training program were organized prior to full adoption and use of computers and other ICTs. Only $73 \%$ of respondents affirmed that ICT is given due consideration in board deliberations.

Referring to executive sample of the insurance companies, the marketing managers and IT managers, $40.3 \%$ of them strongly agree that the adoption and use of ICTs in their organization has helped to improve organizational management, 39.9\% agree, 2.8\% strongly disagree, while 17\% were not sure and hence remain undecided. When asked for the impact of the ICT application to the reduction of the cost of running their companies, $36 \%$ strongly agree, $48 \%$ agree, $4 \%$ strongly disagrees, $0.8 \%$ disagree, and $11.2 \%$ remain undecided about the assertion. When asked for the impact of ICT on productivity, $29.3 \%$ strongly agreed, while $66.8 \%$ agreed, while $3.2 \%$ strongly disagreed. Another $0.7 \%$ disagreed with the assertion. When asked for the impact of the ICT in the organization value chain, $47 \%$ of the respondents strongly agree to this, while $52 \%$ agree. No dissent was recorded for the assertion.

When asked for the impact of ICT use, in the relation with the customers, $82 \%$ of the respondents confirmed that they had experienced an increased number of customer patronage cases due to the application of ICT in their organization, $12 \%$ of respondents said that they are yet to experience an increase in customer patronage, and $7 \%$ were not sure and hence categorized as being undecided.

When asked if it worth such an investment in the ICT in their companies, for $81 \%$ of insurance executives and managers sampled in the survey the answer was YES. Only $2.8 \%$ of them answered no and $15 \%$ are yet to make up their minds, and hence categorized as being undecided. About the impact that ICT use had in the revenue, only $53 \%$ of them answered that the adoption and use of ICTs has led to an increase in revenue earnings for their companies, while 17\% showed dissent by saying NO, 30\% were undecided on the revenue issue. It was interesting to find out that most of the insurance companies included in the research, do not see ICT as direct means to an end, they see it as a necessary tool for their operations.

Using a cross section of insurance IT managers, we found out that $18 \%$ were part of the ICT implementation process within their companies and 14\% IT managers said that they were not part of the implementation process, but have a good understanding of the system already in place.

About technical issues on ICT implementation, we found out that the type of network being managed also varies 
from company to company. Only $6.7 \%$ of IT managers said that they operate a distributed network, while $17.5 \%$ said that they were on a client/server network.

Referring to the employees answers, we found out that about $81 \%$ of employees and personnel of the insurance companies included in the research have computers access to their offices for official duties. About $92 \%$ of insurance companies sampled have internet facility. Official uses by employees of the Internet during the working day were electronic-mail, information search, visiting websites and online discussion. Using the electronic mailing system to send and receive information was the most official use of Internet facilities within the company. Computers, printer, facsimile, internet telephony, mobile phones, were the most used ICT in the insurance companies. Other ICTs such as video conferencing, video telephony and mobile radio were hardly used by majority of these companies. Mobile phones whether privately owned or not has also been put to good use by employees and personnel to communicate information for business and official reasons. Most junior employees agreed that they have experience increased productivity since the adoption and use of ICTs within their company.

\section{Conclusions}

Referring to the research results, most insurance executives and senior managers strongly hold the view that ICTs has led to an increase in organizational productivity, while others merely agree. Referring to the literature review, Stairs and Reynolds (2001), it is important to understand that ICT is not productive by itself. Benefits of using ICT in insurance companies, are divided in two groups: tangible and intangible. In the first group are included timeliness of insurance operations, adequate information storage facilities, faster means of communication and reduction in the amount of effort put into work. In the second group are included customer satisfaction and good corporate image.

Referring to the literature review, different researchers have argued that aside the benefits, there are other factors that make the adoption of the ICT by insurance companies necessary.

The adoption of ICT use among the insurance companies is become a necessity, taking in consideration the need faster insurance operation, faster processing of customer claims and companies liabilities. Most insurance companies in Albania, now see the need to include ICTs in their business goals even though they face the challenges of formulating the right policies that should strategically position ICTs for effective service delivery to their customer. Engagement of the qualified professional and consultants within the insurance companies who will be responsible for the ICT use, is a very important decision to be taken in consideration by the executives and decision makers. They are aware that positioning ICT strategically, a much better perception and utilization level should take place.

\section{References}

Bazini, E., Elmazi, L., \& Sinanaj, Sh. (2012). Importance of Relationship Marketing Management in

Bazini, E., Ilia, D., \& Qarri, A. (2011). Barriers of ICT Implementation within SMEs in service sector in Albania". EuroEconomica 01/2011; 2(29):114-120.

Coviello, A. The impact of ICT in the insurance industry: the role of Customer Relationship Management.

Coviello. A., Trapani. G. (2013). Impacts of ICT Application on the Insurance Sector (E-Insurance). Proceedings of the $1^{\text {st }}$ Global Virtual Conference. April, 8. - 12. 2013. Available online at: http://www.gv-conference.com.

Ganesh,S., Babasaheb, S., Kaba., Momanyi K.W. \& Jibia. M.S. (2013). Integrating ICT in Insurance Management: Design \& Development of an Online Insurance System for E. Africa Insurance Company. Journal of Information Engineering and Applications, Vol.3, No.5, 2013, ISSN 2224-5782 (print) ISSN 2225-0506 (online). Available online at: www.iiste.org

Madani, F., Muharremi, O., \& Pelari, E. (2013). The Effect Remittances Have on the Living Standards of Albanians and on Country's GDP", Mediterranean Journal of Social Sciences, Vol 4 No 11 October 2013. E-ISSN 2039-2117, ISSN 2039-9340.

Madani.F., Bazini.E., (2013). The role of Insurance companies in albanian economy Journal of Academic Research in Economics. Volume 5, Number 1, June 2013, 147-161. ISSN: 2066- 0855.

Mrs. Madhuri Ravindra Godbole3. IBMRD's Journal of Management and Research, Print ISSN: 2277-7830, Online ISSN: 2348-5922

Qarri, A., Bazini, E., \& Leskaj, B. (2011). The impact of ICT use in competitive advantage in SME-s within service sector in Albania. Journal of Information Technology \& Economic Development . 2011, Vol. 2 Issue 1, p9-19. 11p.

Ramaj, A., \& Bazini, E. (2013). Database Marketing Use as a Tool of Knowledge Management within Firms in Albania. Mediterranean Journal of Social Sciences, Vol 4 No 11 October 2013. E-ISSN 2039-2117, ISSN 2039-9340.

Razaq, A.O. (2010). Evaluation of ICT Penetration in Selected Insurance Companies: The Lagos Experience. Journal of Emerging Trends in Computing and Information Sciences. Volume 1, No. 1, July 2010. ISSN 2079-8407. Available on line at http://www.cisjournal.org.

Requena, J.V., Sellens. J.T., \& Jime'nez-Zarco, A.I. ICT use in marketing as innovation success factor Enhancing cooperation in new product development processes. European Journal of Innovation Management Vol. 10 No. 2, 2007 pp. 268-288. 
www.emeraldinsight.com/1460-1060.htm

Ryals, L. (2001). Customer relationship management in financial services: towards information-enabled relationship marketing. Journal of Strategic Marketing, 3/1/2001.

Salatin. P., Yadollahi. F., \& Eslambolchi. S. (2014). The effect of ICT on insurance industry in selected countries. Research Journal of Economics, business and ICT, Volume 9, Issue 1, 2014. ISSN 2045-3345. http://www.journals.cz.

Sapprasert. K. (2006). The impact of ICT on the growth of the service industry. Proceedings of International Conference "Knowledge, innovation and competitiveness: Dynamics of firms, networks, regions and institutions. Copenhagen, Denmark, June 18-20, 2006.

The Insurance Business in Albania. Procedia - Social and Behavioral Sciences, Volume 44, 2012, Pages 155-162. 2012.

Thuo. K.J., Kibera, F.N., \& K'Obonyo, P.O., \& Wainaina. G. Customer Relationship Management and Competitiveness of Commercial Banks in Kenya.

www.cisjournal.org

i2tic.net

www.cersi.it

www.cometmoney.com

www.gv-conference.com 